\title{
ASSESSMENT OF THE IMPACT OF THE ODRA RIVER WATER LEVELS ON GROUNDWATER LEVELS IN RZECZYCA REGION
}

\author{
MieCZySŁaW CHALFEN \\ Department of Mathematics, Wrocław University of Environmental and Life Sciences, \\ ul. Grunwaldzka 53, 50-357 Wrocław, mieczyslaw.chalfen@up.wroc.pl
}

\section{Beata GluchowsKa}

Regional Water Management Board in Wrocław, ul. C.K. Norwida 34, 50-950 Wrocław, beata.gluchowska@wroclaw.rzgw.gov.pl

\section{LESZEK PŁYWACZYK}

Department of Environmental Protection and Development, Wrocław University of Environmental and Life Sciences, pl. Grunwaldzki 24, 50-363 Wrocław, leszek.plywaczyk@up.wroc.pl

\begin{abstract}
Groundwater table levels in a river valley depend, among other factors, on meteorological and hydrogeological conditions, land use and water levels in watercourses. The primary role of a watercourse is to collect surface and groundwater, and it becomes an infiltrating watercourse at high water levels. Changes in groundwater levels and the range of these changes depend chiefly on the shape, height and duration of the flood wave in the river channel.

The assessment of flood wave impact on groundwater was based on long-term measurements of groundwater levels in the Odra valley and observations of water levels in the river channel. Simulations were performed with the use of in-house software FIZ (Filtracja i Zanieczyszczenia; Filtration and Contamination), designed for modelling unsteady water flows within a fully saturated zone. A two-dimensional model with two spatial variables was employed. The process of groundwater flow through a porous medium, non-homogeneous in terms of water permeability, was described with Boussinesq equation. The equation was solved with the use of finite element method. The model was applied to assess groundwater level fluctuations in the Odra valley in the context of actual flood waves on the river.

Variations in groundwater table in the valley were analysed in relation to selected actual flood water levels in the Odra in 2001-2003 and 2010. The period from 2001 to 2003 was used to verify the model. A satisfactory agreement between the calculated and the measured values was obtained. Based on simulation calculations, it was proved that flood waves observed in 2010 caused a rise in groundwater table levels in a belt of approximately 1000 metres from the watercourses. It was calculated that at the end of hydrological year 2009/2010, the highest growths, of up to $0.80 \mathrm{~m}$, were observed on piezometers located close to the Odra river channel. The passage of several flood waves on the Odra caused an increase of subsurface retention by $3.0 \%$ compared to the initial state.
\end{abstract}




\section{INTRODUCTION}

The groundwater level in a river valley is influenced by many different factors. Two of them are water levels in the river channel and their amplitude affecting the position and fluctuations of groundwater table in the adjacent area. In the analysed section, the river has drainage character in relation to the neighbouring parts of the valley. The existing hydrogeological system enables good contact of surface waters with groundwater in the valley.

The amplitude of groundwater table fluctuations caused by water levels in the river depends chiefly on the distance from the river channel, hydrogeological and meteorological conditions, fluctuation amplitude and the duration of flood-water period in the river.

\section{RESEARCH AREA}

The area under study lies in the Odra River valley. Its width varies from c. $1.0 \mathrm{~km}$ near Malczyce to c. $4.0 \mathrm{~km}$ in the area of Brodno. The longitudinal gradient of the valley varies from 0.1 to $0.5 \%$, the local transverse slopes are $4-15 \%$. The river Odra has a typically lowland character. The mean gradient of the river bed is c. $0.25 \%$ [3]. The area of the left-bank Odra valley contains the watercourses of Średzka Woda and Jeziorka, delimiting the area of interest from the south; in the north it is bounded by

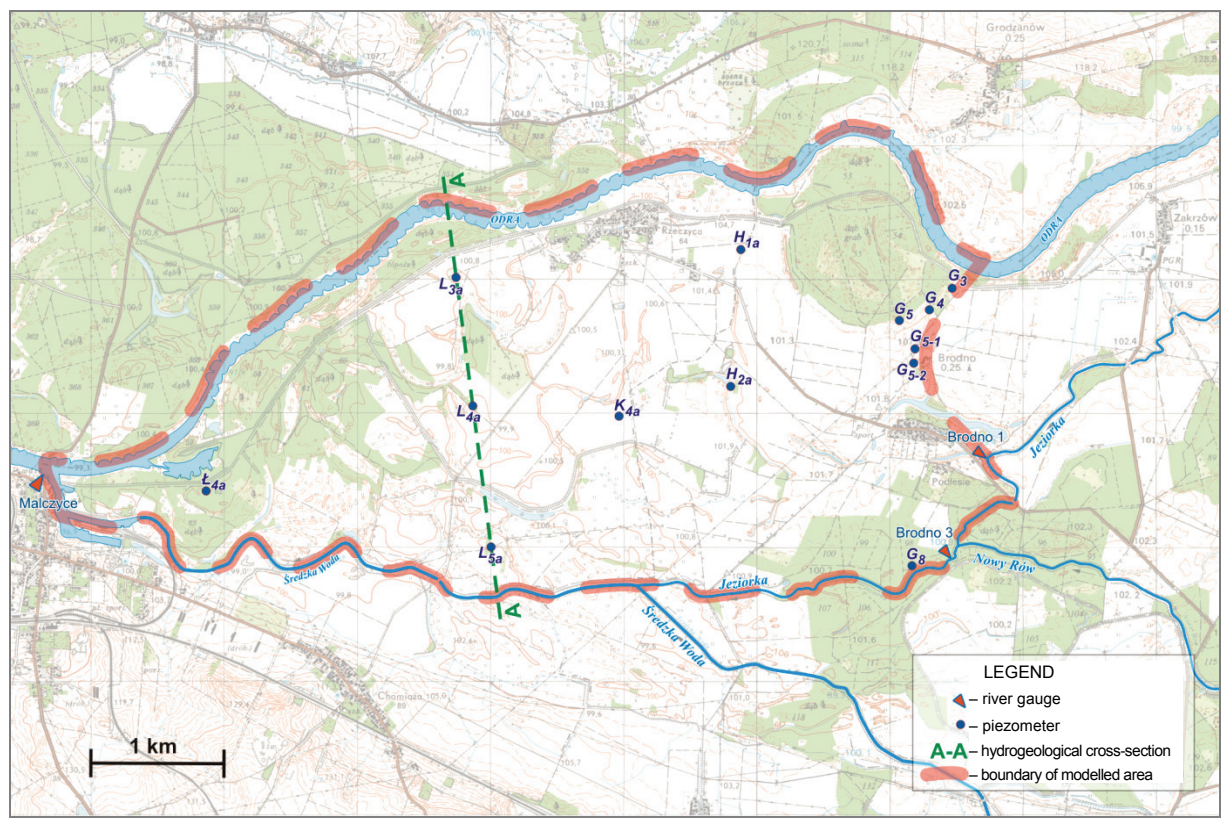

Fig. 1. The area being researched and location of piezometers 
the river Odra and in the east - by the line connecting piezometers placed perpendicularly to the Odra (Fig. 1). The Średzka Woda is a left-bank tributary of the Odra and it joins the Odra at $304+800 \mathrm{~km}$ in the town of Malczyce. The terrain in the lower part of the Średzka Woda catchment, located within the Odra valley, is rather flat. The longitudinal slope is c. $0.76 \%$ and the mean transverse slope - c. $9.4 \%$. The Jeziorka is a right-bank tributary of the Średzka Woda. The distance of its channel from the Odra channel varies from c. $2.0 \mathrm{~km}$ (at Brodno 1 gauging station) to c. $3.5 \mathrm{~km}$ (at its confluence with the Średzka Woda). The relief of the catchment is unvaried, its longitudinal slope is c. $0.30 \%$ and the mean transverse slope - c. $5.0 \%$. In the left-bank Odra valley, below the barrage in Brzeg Dolny, measurements of groundwater table depth were performed at measurement points (piezometers and household wells). Their distribution is shown in Fig. 1. The FIZ model was verified with the use of groundwater table depth measurements made at selected observation points in 2001-2003 [11].

\section{HYDROGEOLOGY}

The geological-engineering documentation [10] points to the occurrence of Quaternary and Tertiary formations in the analysed part of the Odra valley. The Quaternary formations include: Holocene deposits - fluvial deposits, chiefly sands and alluvial

Fig. 2. Schematic hydrogeological cross-section through the Odra valley; section A-A

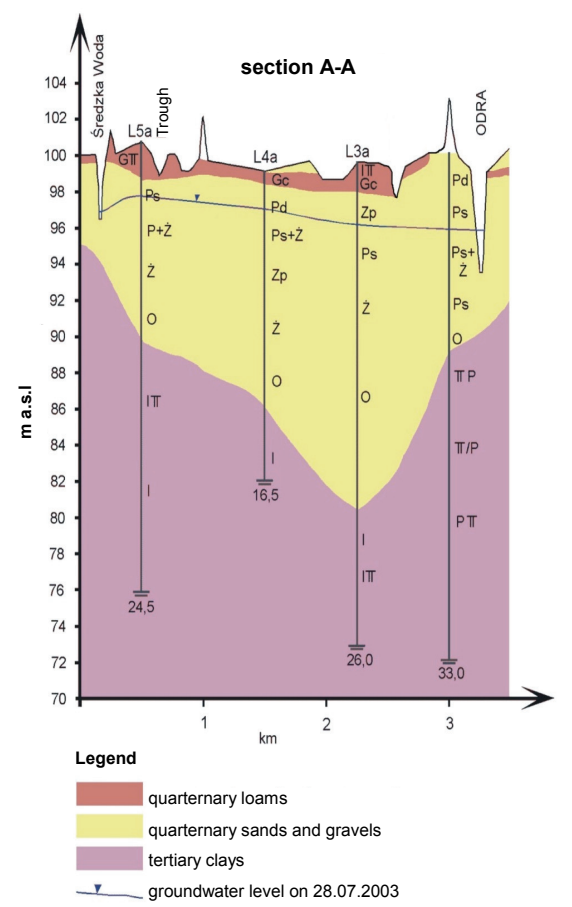


gravels (c. $4.5 \mathrm{~m}$ thick) as well as alluvial soils and organic muds (varying in thickness from $0.5 \mathrm{~m}$ to $3.5 \mathrm{~m}$ ) and Pleistocene formations - glacial, fluvioglacial and fluvial deposits, including gravels and fluvial sands (varying in thickness from $14 \mathrm{~m}$ to $30 \mathrm{~m}$ ) overlying Tertiary clays. The Tertiary deposits are represented by Pliocene clays forming an impermeable layer covered by Quaternary formations. The roof of Tertiary clays lies at the depth from several to about a dozen metres, and local denivelations reach about $30 \mathrm{~m}$. The aquifer in the valley is formed of sands, sand-gravels and Holocene and Pleistocene gravels. The hydraulic conductivity varies from 0.86 to $4.32\left[\mathrm{~m} \cdot \mathrm{day}^{-1}\right]$ for sands and from 3.46 to $138.20\left[\mathrm{~m} \cdot \mathrm{day}^{-1}\right.$ ] for gravels. The groundwater table in the analysed part of the Odra valley is located in sand-gravel aquifers. The existing hydrogeological system creates favourable conditions for contact between the waters in the Odra and other watercourses and the groundwater in the valley. [8]. Figure 2 presents a schematic hydrogeological cross-section through the Odra valley.

\section{MATHEMATICAL MODEL}

In order to investigate seepage conditions, a mathematical model was employed, describing groundwater flow in a saturated zone in a planar cross-section, for unconfined or confined flow regimes. This model is dynamic in time, in a system of two spatial variables. The model allows for heterogeneity and anisotropy of the soil medium, spatial and temporal variation of boundary conditions, and it also enables the infiltration seepage from aeration zone to be taken into consideration.

The model is based on the Boussinesq equation

$$
\mu \cdot h_{t}=\left(T_{1} \cdot h_{x}\right)_{x}+\left(T_{2} \cdot h_{y}\right)_{y}+W
$$

where:

$$
\begin{array}{ll}
x, y & - \text { spatial coordinates }[\mathrm{m}], \\
t & - \text { time }[\mathrm{d}], \\
h(x, y, t) & - \text { piezometric height } h \text { at a point with coordinates } x, y \text { at a moment } t[\mathrm{~m}], \\
\mu & - \text { depends on seepage type: }
\end{array}
$$

For unconfined seepage: specific field [-],

For confined seepage: specific storage $[-]$,

$T \quad-$ water transmissivity of the stratum - depending on seepage character $\left[\mathrm{m}^{2} \cdot \mathrm{d}^{-1}\right]$

For unconfined seepage: $T=k \cdot(h-a)$,

For confined seepage: $T=k \cdot m$,

$k \quad-$ hydraulic conductivity $\left[\mathrm{m} \cdot \mathrm{d}^{-1}\right]$,

a - aquifer floor depth [m], 
$m \quad-$ aquifer thickness [m],

$W \quad$ - source function $\left[\mathrm{m} \cdot \mathrm{d}^{-1}\right]$.

Equation (1) was supplemented with an initial condition, defining piezometric heads at the start of simulation, and Dirichlet, Neumann or mixed boundary conditions. The differential problem, composed of a differential equation (1) supplemented with initial/boundary conditions, was solved with finite element method [4], [14]. In the model, the filtration area was divided into triangular elements. The unknown function, i.e. the piezometric head within each finite element, was approximated with basis functions - linear functions were used in the model [13].

The solution obtained was piezometric heads in triangle vertices, which were used for defining the vectors of water flow velocity and flow rate, hydroisohypses, hydroisopiezes, flow path, streamlines and hydrodynamic mesh. The computer realisation of the model adopted is the in-house software FIZ (Filtracja i Zanieczyszczenia; Filtration and Contamination) [1], [2].

\section{DISCRETIZATION OF RESEARCH AREA}

The analysed area is bounded by the Odra from $296+00 \mathrm{~km}$ to Malczyce gauging station $(304+00 \mathrm{~km})$ in the north and by the Jeziorka from $2+80 \mathrm{~km}$ to its confluence with Średzka Woda and further to the confluence of the Średzka Woda and the Odra in the south. The surface area of this zone is $15.44 \mathrm{~km}^{2}$. The WE extent is $7250 \mathrm{~m}$ and NS $-3460 \mathrm{~m}$. The adopted aquifer thickness is from 5.00 to $26.45 \mathrm{~m}$, on average $11.69 \mathrm{~m} \mathrm{[10]}$. It was assumed that near the terrain surface there is a 2-metre thick poorly permeable layer. The hydraulic conductivity value oscillates from 9.50 to $20.3 \mathrm{~m} \cdot \mathrm{d}^{-1}$ and it averages $15.76 \mathrm{~m} \cdot \mathrm{d}^{-1}$ [10]. The adopted specific yield coefficient for unconfined seepage $\mu$ was 0.15 to 0.28 , on average 0.22 , while specific storage for confined seepage was assumed to be uniform for the whole area and it reached $\mu=0.001$ [5]. Confined seepage occurred only at flood water levels in the N-E area, in the zone adjacent to the Odra channel.

The Odra, the Jeziorka and the Średzka Woda were simulated as partially penetrating watercourses. The Dirichlet condition, consistent with water levels in watercourses was used, and hydraulic conductivity was modified near the watercourses to offset additional hydraulic resistances resulting from partial penetration. On the eastern bank, Neumann condition was assumed, with flow rate $q=0.136 \mathrm{~m}^{3} \cdot \mathrm{d}^{-1} \cdot \mathrm{mb}^{-1}$ estimated from aquifer thickness, hydraulic conductivity and mean hydraulic head gradient in boundary nodes. Infiltration from the aeration zone was assumed to be constant in time for the whole area and amounting to $17 \%$ of the mean annual rainfall [7] equal to $0.3 \mathrm{~mm} \cdot \mathrm{d}^{-1}$.

The model discretization mesh consisted of 7739 nodes and 15069 triangles with average side length below $50 \mathrm{~m}$. The mean maximum angle in the triangle is $62^{\circ}$, 
which demonstrates that all the triangles have shapes comparable to equilateral triangles. In all the calculations, time step of 1 day was used.

\section{MODEL VERIFICATION}

The model was verified with the use of measurement data collected from about a dozen of piezometers in 2001-2003. Water levels in the Odra, the Jeziorka and the Średzka Woda, in particular boundary nodes of discretization mesh were determined from the mean annual readings at Malczyce, Brzeg Dolny, Brodno 1 and Brodno 3 gauging stations, allowing for bed slope of the above watercourses. The calculations were conducted until the stabilization of the filtration process. Calculation results were compared to annual mean values of piezometers (Table 1)

Table 1

Observed and calculated values of groundwater tables in piezometers

\begin{tabular}{|c|c|c|c|c|c|c|c|c|c|c|c|c|c|}
\hline $\begin{array}{c}\text { Piezo- } \\
\text { meter }\end{array}$ & G3 & G4 & G5 & G5-1 & G5-2 & G8 & H1a & H2a & K4a & L3a & L4a & L5a & Ł4a \\
\hline Obs. [m] & 98.71 & 98.98 & 99.46 & 99.36 & 99.52 & 99.25 & 99.02 & 98.92 & 98.60 & 97.56 & 97.69 & 98.02 & 96.34 \\
\hline Calc. [m] & 99.17 & 99.47 & 99.46 & 99.66 & 99.65 & 98.90 & 98.47 & 98.93 & 98.50 & 97.27 & 97.96 & 97.81 & 96.82 \\
\hline
\end{tabular}

It was found out that the mean absolute error $\delta$ calculated from the formula

$$
\delta=\frac{1}{n} \sum_{i=1}^{n}\left|H_{\mathrm{obs}_{i}}-H_{\mathrm{calc}_{i}}\right|
$$

where:

$H_{\text {obs }}$ - observed values,

$H_{\text {calc }}$ - calculated values, was $0.28 \mathrm{~m}$. The coefficient of correlation between the measured and calculated values is $r=0.93$ and the determination coefficient $R^{2}=0.87$, which enables qualifying model adjustment as good [12]. Figure 3 presents the comparison of measured and calculated values by means of the model.

Figure 4 presents the hydroisohypse pattern calculated on the model. It is consistent with the observed long-term datum pattern of the groundwater table [9]. The drainage character of the Odra and the Średzka Woda is manifested, which is characteristic of medium water levels in watercourses. The watershed line is close to the actual one [3]. 


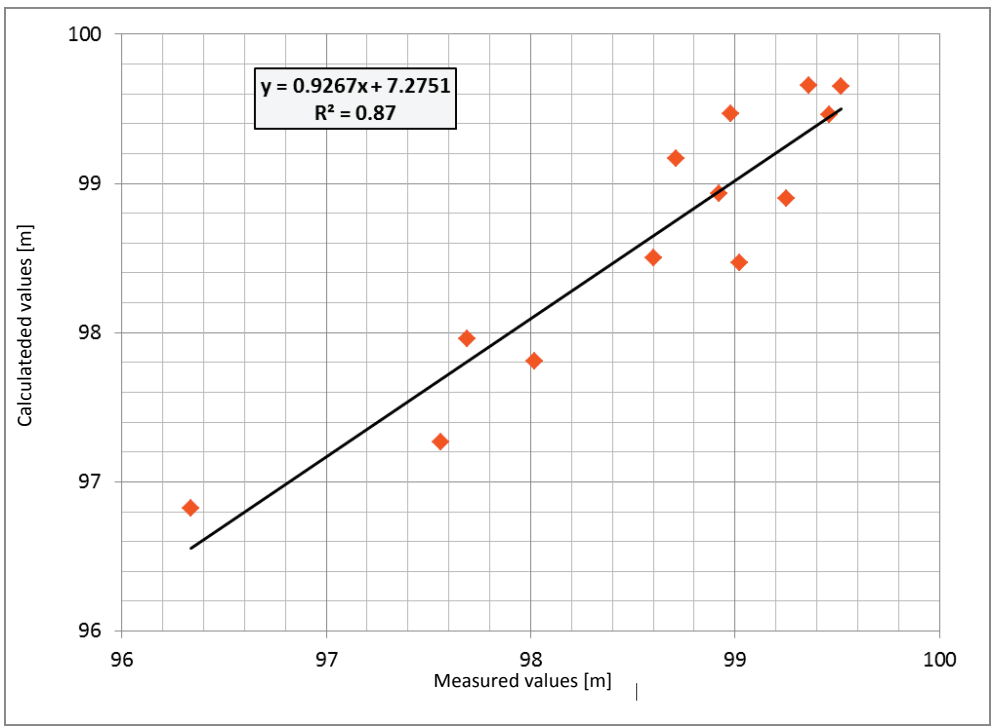

Fig. 3. Comparing measured and calculated values at the stage of model verification

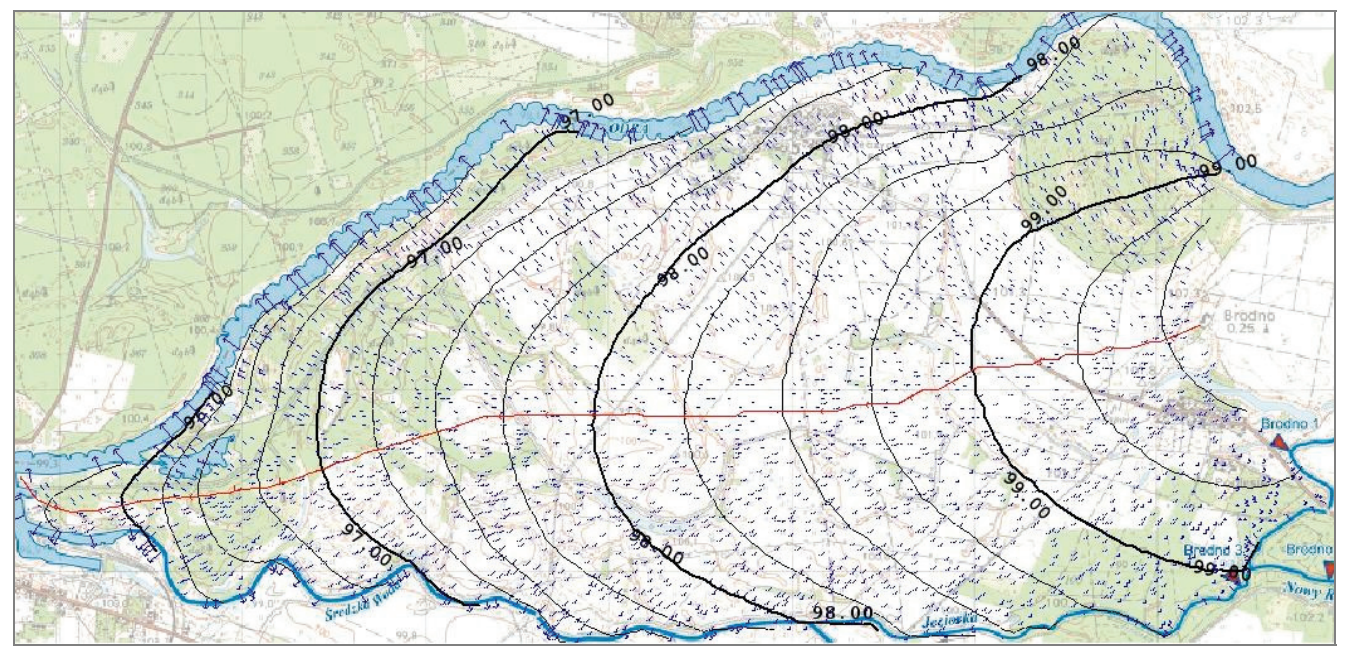

Fig. 4. Calculated groundwater table levels; flow directions and watershed line in 2002. $\leftarrow$ groundwater flow direction; $\mathbf{9 9 . 0 0}$ hydroisohypses; - - watershed line

\section{FLOOD WAVES IN 2010}

Oscillations in groundwater levels in piezometers located in the area under study could be due to a number of different causes: changes in water levels in watercourses, 
precipitation and atmospheric transpiration, spring thaw, local water collection sources, etc. Generally, these causes overlap, so it is only through observations of piezometric indications that one can determine the influence of particular factors on changes in groundwater depth [6].

The model being studied and verified was employed to analyse the influence of changing water levels in the Odra, the Jeziorka and the Średzka Woda on groundwater levels on the example of flood waves in 2010.

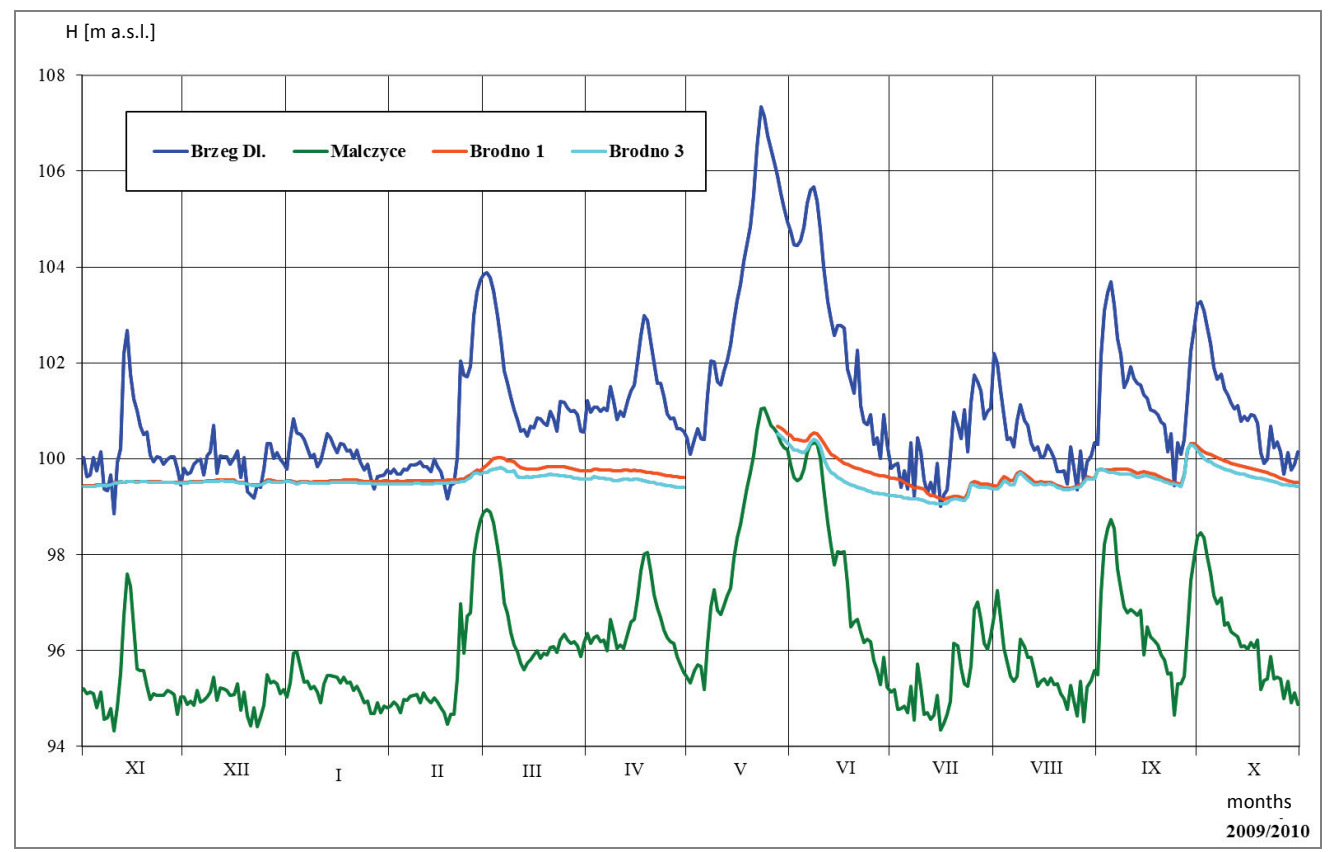

Fig. 5. Hydrographs of water levels in watercourses in hydrological year 2009/2010

(gauging stations: Brzeg Dolny, Malczyce, Brodno 1, Brodno 3)

Observations of water levels on the Odra at Brzeg Dolny and Malczyce gauging stations and Brodno 1 and Brodno 3 gauging stations on the Jeziorka were used. Simulations of changes in groundwater depth in hydrological year 2009/2010 were conducted, and the values calculated from the model were compared with groundwater level on 1st November 2009. The first day of hydrological year, i.e., 1st November 2009 , was adopted for analyses as the period preceding the calculations was characterised by steady boundary conditions. 


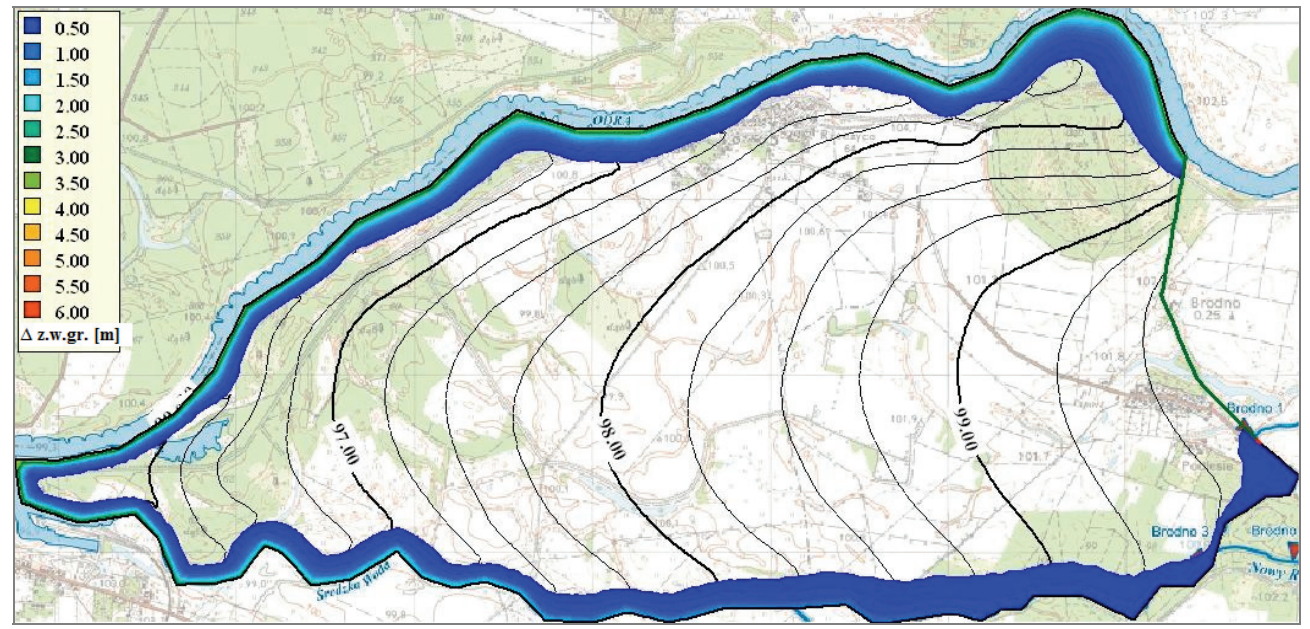

Fig. 6. Hydroisohypse pattern and changes in groundwater table depth at the peak of flood wave (3rd March 2010); $\Delta$ z.w.gr. (m) - changes in groundwater table depth

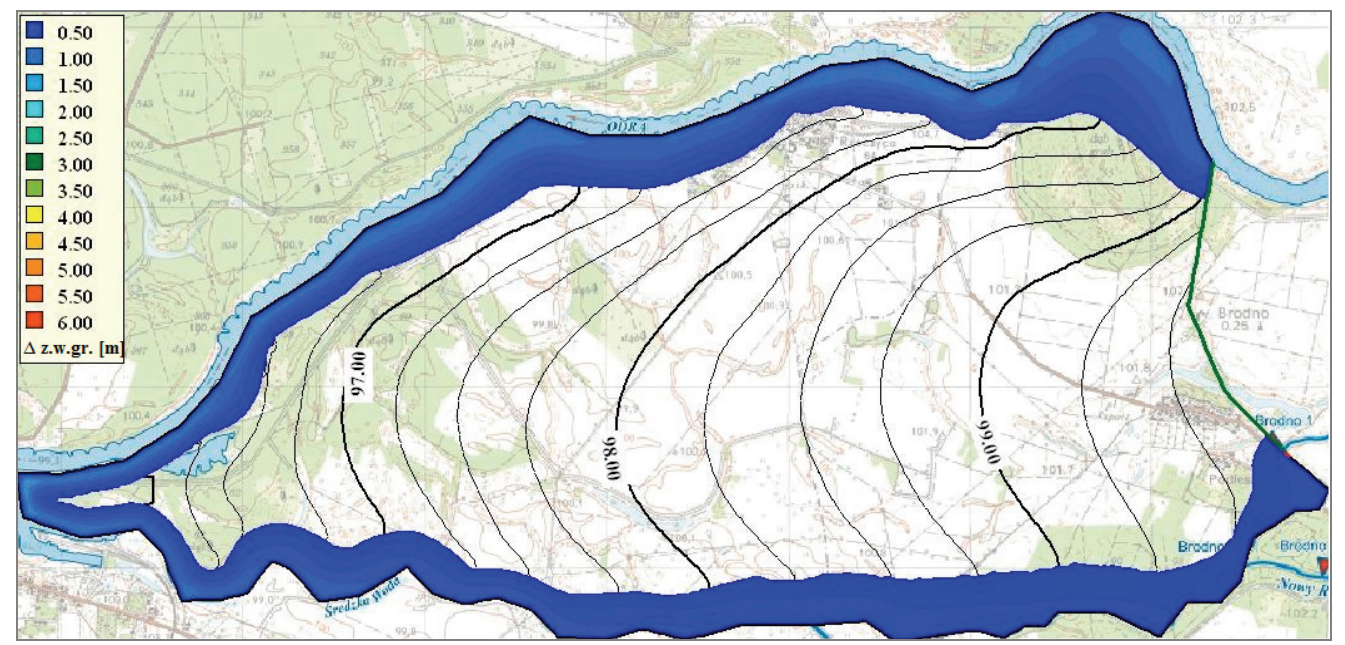

Fig. 7. Hydroisohypse pattern and changes in groundwater table depth after the passage of flood wave (14th March 2010); $\Delta$ z.w.gr. [m] - changes in groundwater table depth

Spring flood (at the turn of February) lasted less than four weeks, the flood wave height recorded at Brzeg Dolny and Malczyce gauging stations exceeded $5.0 \mathrm{~m}$. This caused a rise in groundwater level in a belt of c. $200 \mathrm{~m}$ from both watercourses (Figs. 6-7). In Figs. 6 and 7, the area where growths were higher than $0.1 \mathrm{~m}$ is plotted. On the peak day, i.e., 3rd March 2010, the highest growths were recorded in the area directly adjacent to the Odra channel and they reached nearly $3.5 \mathrm{~m}$ (Fig. 6). On the day 
of wave end - 14th March 2010, increase did not exceed $1.0 \mathrm{~m}$ and in the area near Brodno 3 gauging station they were smaller than $1.0 \mathrm{~m}$ (Fig. 7). High water levels in the river caused water inflow to the near-channel zone of the Odra.

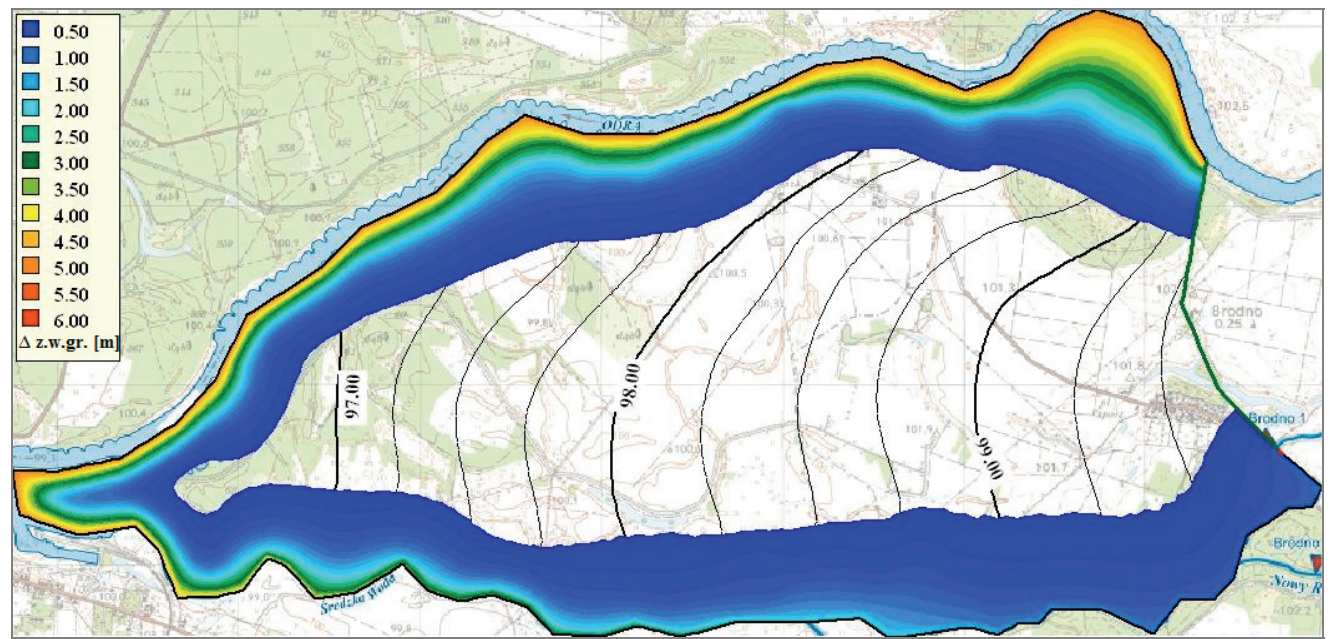

Fig. 8. Hydroisohypse pattern and changes in groundwater table depth at the peak of flood wave (23rd May 2010); $\Delta$ z.w.gr. [m] - changes in groundwater table depth

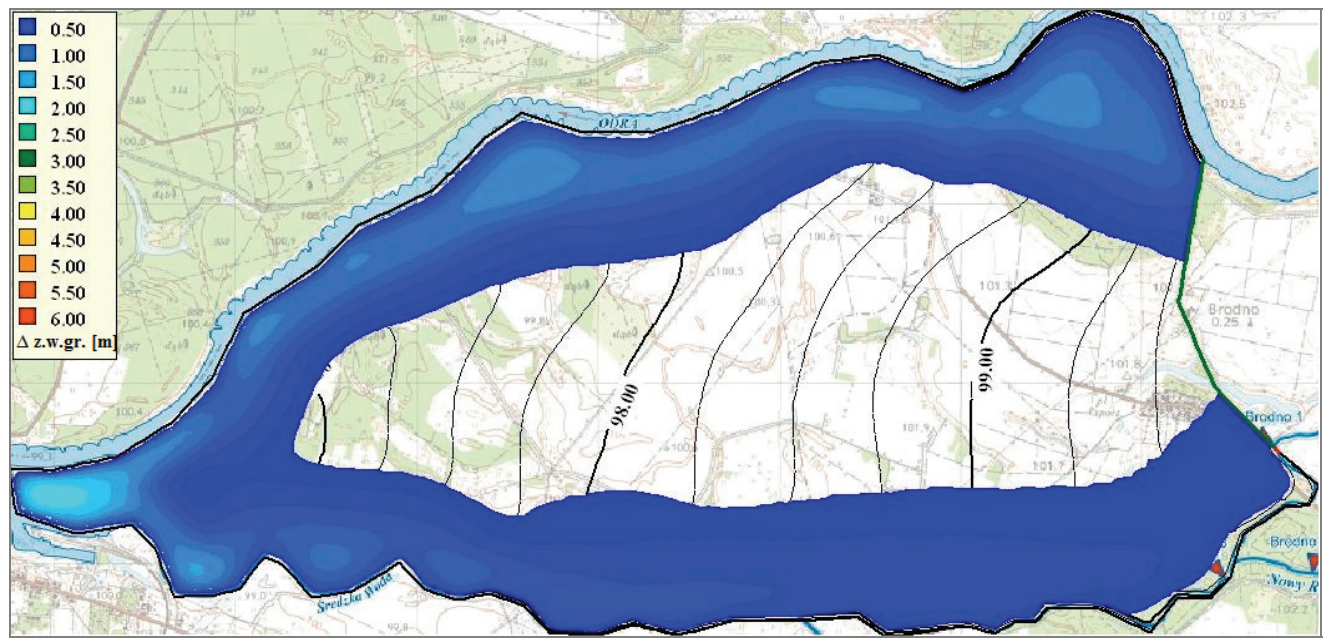

Fig. 9. Hydroisohypse pattern and changes in groundwater table depth after the passage of flood wave (28th June 2010); $\Delta$ z.w.gr. [m] - changes in groundwater table depth

The May/June wave was longer (it lasted c. 2 months) and higher (floodwater height at Brzeg Dolny and Malczyce gauging stations exceeded $6.0 \mathrm{~m}$ ) than the Febru- 
ary/March one (Figs. 8 and 9) and it caused bigger changes in groundwater level than the spring wave both in terms of its extent and groundwater table increase. After the last day of the wave peak - 28th June 2010 (Fig. 9), groundwater rose in the belt c. $1 \mathrm{~km}$ wide and the biggest growths reached $5.0 \mathrm{~m}$ (Fig. 8). In the phase of subsidence of the Odra waters, the range of groundwater level changes still grew, while the largest growths did not exceed $2.5 \mathrm{~m}$. In the eastern part of the modelled area, after the passage of the wave, it is observed that both the Odra and the Jeziorka are water-receiving bodies.

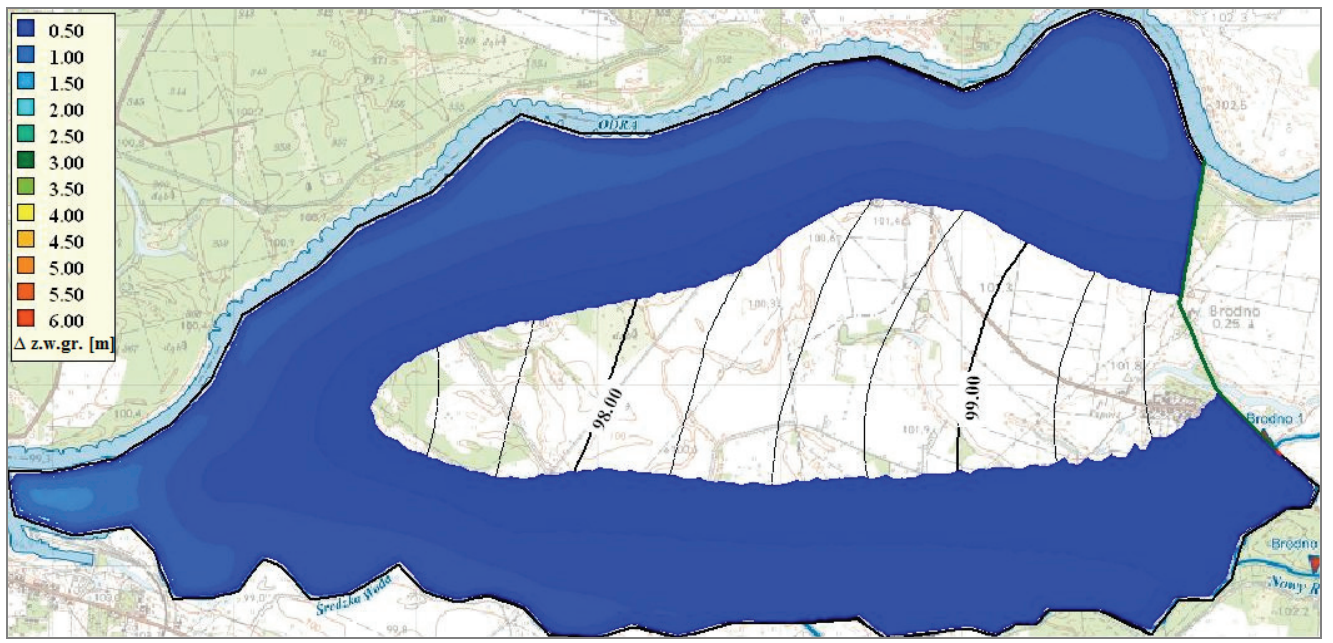

Fig. 10. Hydroisohypse pattern and changes in groundwater table depth

(31st October 2010)

$\Delta$ z.w.gr. [m] - changes in groundwater table depth

At the end of hydrological year 2009/2010, the area of increased groundwater levels, in relation to the initial state (1st November 2009), did not change basically, which was due to consecutive autumn flood waves.

Figures 11 and 12 depict calculated groundwater datums in selected piezometers. The responses of particular piezometers vary. The biggest changes and the shortest response times were recorded in piezometers placed near the Odra and the Jeziorka channels (G3, G8, L3a) - the growths after the May/June flood wave reached $2.0 \mathrm{~m}$, while practically no significant changes in groundwater table caused by flood wave passage on watercourses were recorded in piezometers located in the central part of the valley, in the watershed area $(\mathrm{K} 4 \mathrm{a}, \mathrm{H} 2 \mathrm{a}, \mathrm{L} 4 \mathrm{a})$. Generally, one can observe a rise in groundwater levels in the whole valley. Figure 13 shows calculated increase of groundwater as a function of distance from the Odra river in several characteristic 


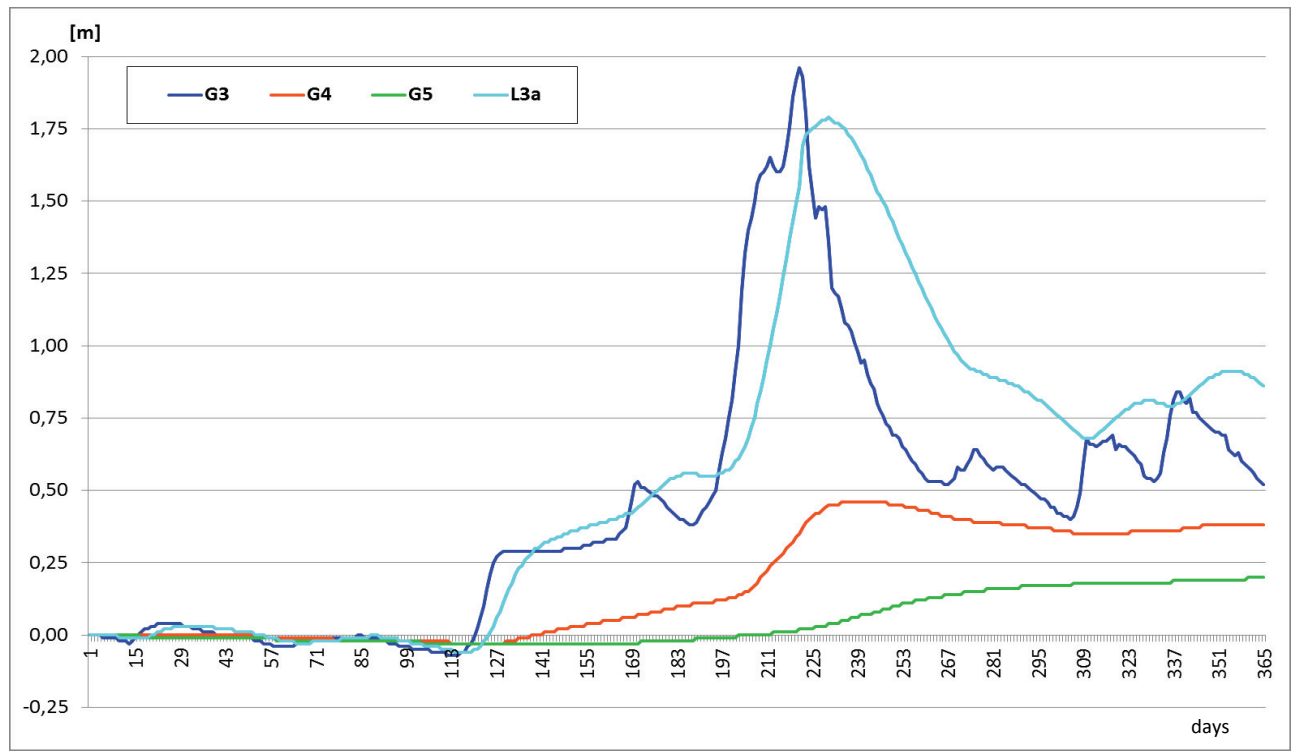

Fig. 11. Groundwater table depth growths in selected piezometers near the Odra (in relation to the 1st November 2009 level)

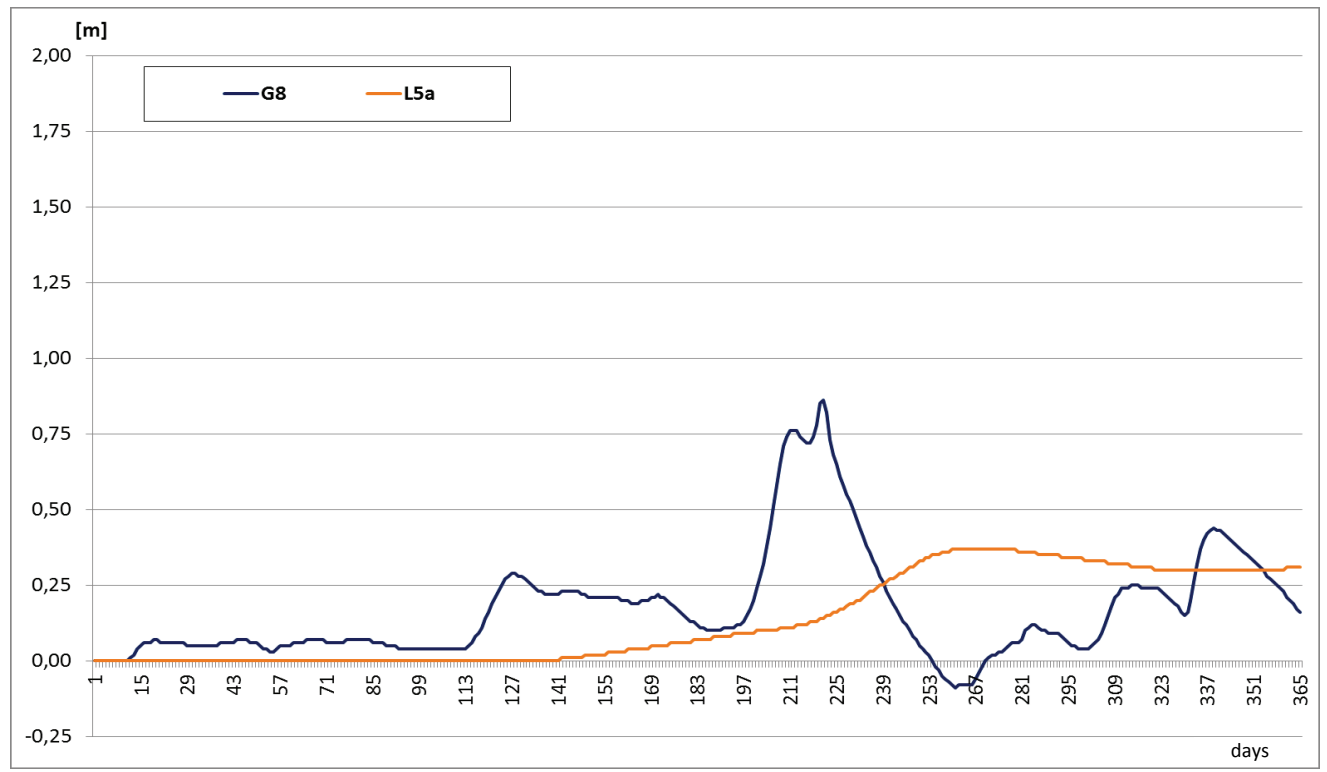

Fig. 12. Groundwater table depth growths in piezometers near the Jeziorka and the Średzka Woda (in relation to 01.11.2009 levels) 


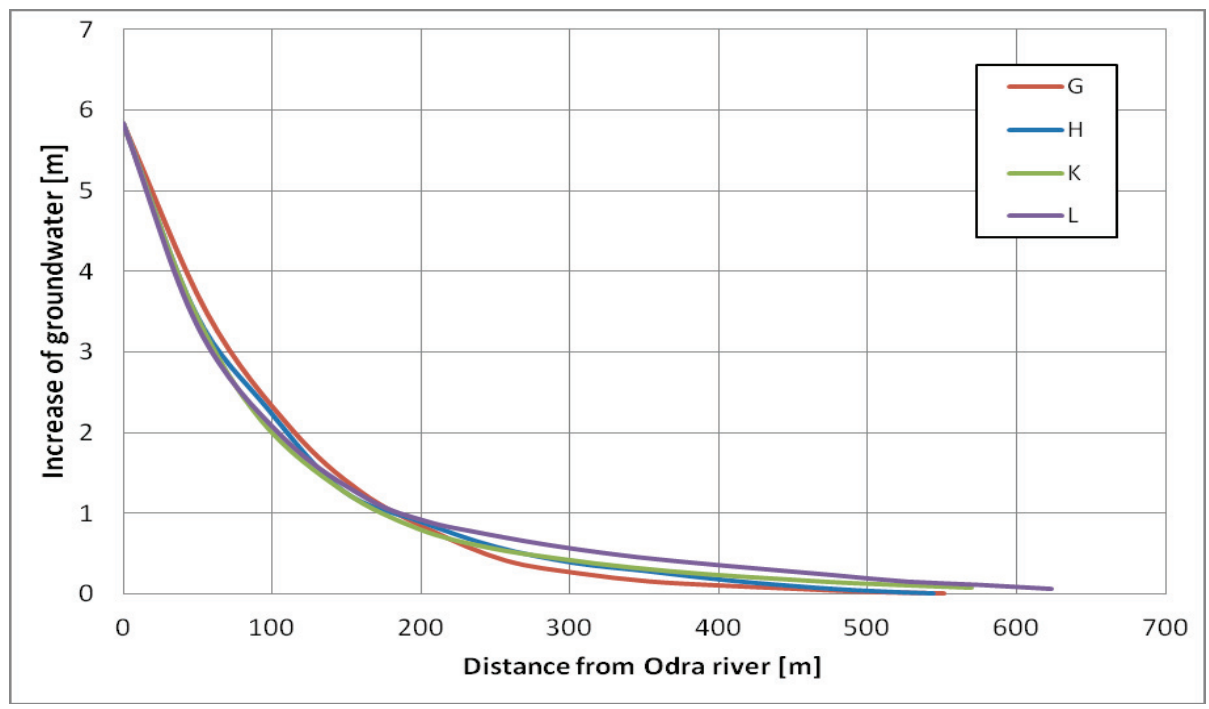

Fig. 13. Increase of groundwater as a function of distance from the Odra River

cross-sections through the valley (see Fig. 1) at 23rd May 2010. This observation is supported by the graph (Fig. 14) showing changes in subsurface retention in hydrological year $2009 / 2010$. The retention value rose by $3.0 \%$ compared to the beginning of hydrological year.

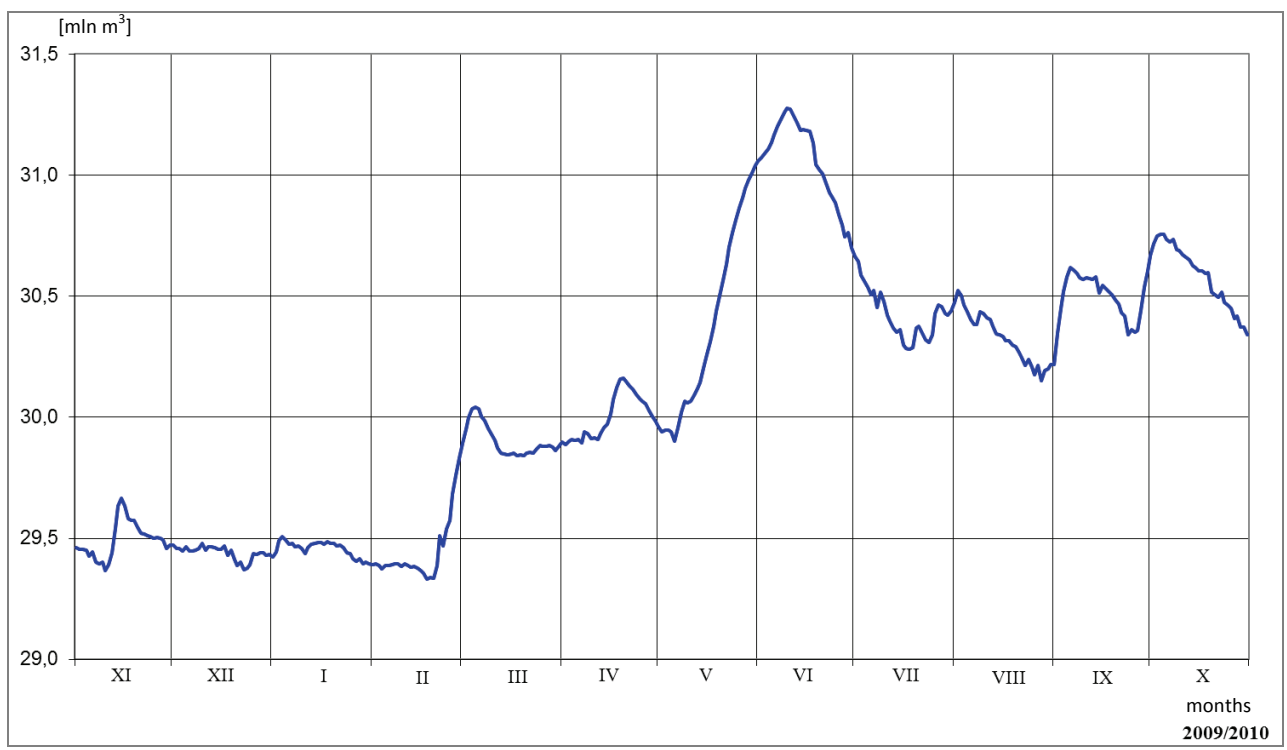

Fig. 14. Changes in subsurface retention in hydrological year 2009/2010 


\section{CONCLUSIONS}

1. Spring high water stage, lasting nearly 4 weeks, caused a rise in groundwater level in a belt with the width of c. $200 \mathrm{~m}$ from both watercourses. On the peak day, the highest growths were recorded in the area directly adjacent to the Odra river channel and they amounted to nearly $3.5 \mathrm{~m}$. At the end of the flood wave, growths did not exceed $1.0 \mathrm{~m}$.

2. The summer wave (May/June) was higher and longer than the spring one and it caused larger changes in groundwater levels, both in terms of range and growths. After the last day of the peak, groundwater rose in a c. $1.0 \mathrm{~km}$ wide belt, and the highest growths reached $5.0 \mathrm{~m}$. At the lowering stage of the Odra waters, the range of groundwater level changes still grew. Most growths were estimated at c. $2.5 \mathrm{~m}$.

3. The response of particular piezometers to water levels in a river is variable. Wells located close to watercourses responded to changes in water levels in a river faster and they were also characterised by higher amplitudes (G3-1.5 m; G8-1.3 m).

4. At the end of hydrological year 2009/2010, the area of increased groundwater level, in relation to the initial stage, basically did not change, which was due to consecutive autumn high water stages. The value of subsurface retention rose by $3.0 \%$ (c. $2 \mathrm{mln} \mathrm{m}^{3}$ ) compared to the beginning of hydrological year 2009/2010.

5 . The groundwater table depth in the zone affected by water levels in the river depends, among other factors, on flood wave height and base and the duration of high water stage (peak and subsidence).

6 . The largest changes in groundwater table depth occur in the valley belt directly adjacent to the river. The modelling research ascertained that the mean range of impact on the adjacent valley reaches is c. $1.0 \mathrm{~km}$.

\section{REFERENCES}

[1] Chalfen M., Description of FIZ (Filtracja i Zanieczyszczenia) software (in Polish), XXXIII Seminarium Zastosowań Matematyki, Kobyla Góra, 2003.

[2] Chalfen M., Głuchowska B., Pływaczyk L., Influence of the wave shape on the Odra on groundwater in the left-bank valley between Brzeg Dolny and Malczyce (in Polish), XXXIV Seminarium Zastosowań Matematyki, Kobyla Góra 2004.

[3] Głuchowska B., Pływaczyk L., Groundwater table in the Odra valley below the barrage in Brzeg Dolny (in Polish), UP Wroc., Monogr. LIV., 2008.

[4] Kinzelbach W., Groundwater modelling, Elsevier, 1986.

[5] Kowalski J., Hydrogeology with geology basics (in Polish), PWN, Warszawa 1987.

[6] Kowalski J., Chalfen M., Molski T., Report „, Impact on water impoundment on Malczyce barrage on water-soil relations in the area of Rzeczyca village (in Polish), Inst. Inż. Środ. AR we Wrocławiu. Wrocław 2004.

[7] Pływaczyk L., Impact of the Odra on water-drainage relations in the valley in Brzeg DolnyMalczyce region (in Polish), Zesz. Nauk. AR Wroc., Rozpr. Hab. nr 68, 1988.

[8] Pływaczyk L., Groundwater recharge with precipitation in the Odra valley in Malczyce region (in Polish), Zesz. Nauk. AR Wroc., Nr 209, 1992. 
[9] Pływaczyk L., Impact of river impoundment on a valley on an example of Brzeg Dolny (in Polish), AR Wroc., Monogr. XI, 1997.

[10] Praca zbiorowa, Geological-engineering documentation for Malczyce barrage (in Polish), PGIBW, Hydrogeo, Warszawa 1968.

[11] Praca zbiorowa 1970-2010, Studies of the impact of planned impoundment of the Odra on Malczyce barrage on water relations in the adjacent areas (in Polish), Inst. Kształt. i Ochr. Środ., AR Wroc., (unpublished).

[12] Sarma P.B.S., Delleur J.W., Rao A.R., Comparison of rainfall-runoff models for urban areas, J. Hydrol., 1973, 18(3-4).

[13] Wosiewicz B., Sroka Z., Walczak Z., Engineering software for analysing steady groundwater flows (in Polish), Gospodarka Wodna, 2005, Nr 2.

[14] Zienkiewicz O.C., Finite elements method (in Polish), Arkady, Warszawa 1972. 